\title{
Overcoming DNA extraction problems from carnivorous plants
}

\author{
by \\ Andreas Fleischmann \& Günther Heubl \\ LMU Munich, Systematic Botany and Mycology, Menzinger Strasse 67, D-80638 Munich, Germany \\ fleischmann@lrz.uni-muenchen.de
}

\begin{abstract}
Fleischmann, A. \& Heubl, G. 2009. Overcoming DNA extraction problems from carnivorous plants. Anales Jard. Bot. Madrid 66(2): 209-215.

We tested previously published protocols for DNA isolation from plants with high contents of polyphenols and polysaccharides for several taxa of carnivorous plants. However, we did not get satisfying results with fresh or silica dried leaf tissue obtained from field collected or greenhouse grown plants, nor from herbarium specimens. Therefore, we have developed a simple modified protocol of the commercially available MachereyNagel NucleoSpin ${ }^{\circledR}$ Plant kit for rapid, effective and reproducible isolation of high quality genomic DNA suitable for PCR reactions. DNA extraction can be conducted from both fresh and dried leaf tissue of various carnivorous plant taxa, irrespective of high contents of polysaccharides, phenolic compounds and other secondary plant metabolites that interfere with DNA isolation and amplification.
\end{abstract}

Keywords: carnivorous plants, DNA extraction, polyphenols, polysaccharides, secondary metabolites, viscous mucilage.

\section{Introduction}

Many carnivorous plants show bright coloured leaves, which serve as visual attractants for insect prey (Juniper \& al., 1989). Most pitcher plants (Cephalotus, Darlingtonia, Heliamphora, Nepenthes and Sarracenia) often have dark red spots, markings, veins or bright coloured leaves which serve as insect guides and probably mimic flowers (Juniper \& al., 1989). Quite often these colour marks result from polyphenolic secondary metabolites (flavonoids or tannins). Polyphenolic compounds are known from several carnivorous plants, for example flavonoids occur in Sarraceniaceae (Sheridan

\section{Resumen}

Fleischmann, A. \& Heubl, G. 2009. Superando problemas de extracción de ADN de plantas carnívoras. Anales Jard. Bot. Madrid 66(2): 209-215 (en inglés).

Probamos algunos protocolos publicados previamente para el aislamiento del ADN de plantas con alto contenido de polifenoles y polisacáridos para varios táxones de plantas carnívoras. Sin embargo, no conseguimos muy buenos resultados ni con tejidos de hojas frescas, ni con tejidos de hojas secadas en gel de sílice obtenidas de plantas colectadas en el campo o cultivadas en los invernaderos, ni de especímenes de herbario. Por lo tanto, hemos desarrollado un protocolo sencillo, modificado del Macherey-Nagel NucleoSpin ${ }^{\circledR}$ Plant kit disponible en el mercado para el aislamiento rápido, eficaz y reproducible de ADN genómico de alta calidad conveniente para la reacción en cadena de la polimerasa. La extracción del ADN se puede realizar en tejidos de hojas frescas o secas de varios táxones de plantas carnívoras, sin importar el grado de contenido de polisacáridos, compuestos fenólicos u otros metabolitos secundarios que interfieren con el aislamiento y la amplificación del ADN.

Palabras clave: plantas carnívoras, extracción del ADN, polifenoles, polisacáridos, metabolitos secundarios, mucílago viscoso.

\& Griesbach, 2001) and Roridula (Wollenweber, 2007). The carnivorous plant members of the order Nepenthales (Aldrovanda, Dionaea, Drosera, Drosophyllum, Nepenthes and Triphyophyllum) are additionally characterised by quinones like plumbagin (Schlauer \& al., 2005). The phenolic metabolite group of phenylethanoid glycosides is mainly restricted to the Lamiales, an observation supported by the presence of acetoside, which was found in both carnivorous families of this order, Byblidaceae and Lentibulariaceae (Schlauer \& al., 2004; Schlauer \& al., 2005).

In those carnivorous plants that trap insects by sticky flypaper traps, such as Drosera, Drosophyllum, 
Triphyophyllum, Byblis and Pinguicula, the leaves are usually densely covered with specialized glands that secrete a water-based viscous mucilage that contains predominantly acidic polysaccharides (Juniper \& al., 1989; Rost \& Schauer, 1977). In the two species of the pre-carnivorous genus Roridula from South Africa, the glue of the sticky traps is resin-based (Lloyd, 1934) and rich in phenolic compounds, such as flavonoids (Wollenweber, 2007).

Both phenolic secondary metabolites and leaf secretions in the mentioned carnivorous plants impede the extraction of DNA from leaf tissue. During homogenization of the plant samples, phenolic components can become oxidized (Loomis, 1974). Oxidized polyphenols are known to bind covalently and therefore irreversibly to DNA molecules and thus interfere with subsequent reactions such as DNA amplification, restriction digest and cloning (Katterman \& Shattuck, 1983; Stange \& al., 1998; Porebski \& al., 1997). Polysaccharides inhibit the enzymatic activity of several enzymes such as polymerases, ligases and restriction endonucleases (Shioda \& MarakamiMuofushi, 1987; Richards, 1988), including Taq polymerase (Fang \& al., 1992) and thus interfere with PCR (polymerase chain reaction). The result is either a very low DNA yield or none at all, or if DNA can be extracted, the remaining secondary metabolites may inhibit further steps in DNA amplification. For example, total genomic DNA isolated from bright coloured leaves of several species of Drosera, Heliamphora and Sarracenia could not be amplified by PCR in our studies. Therefore, genomic DNA extraction in carnivorous plants was acquired from flower material in some cases (A. Fleischmann, unpublished; Müller \& al., 2004), which usually contains lower amounts of polyphenols and polysaccharides than the carnivorous leaves. Unfortunately, flower material is not always available in abundance and many crucial species only flower rarely in cultivation, or removal of flowers from herbarium specimens is not allowed.

Five different protocols for DNA isolation from plants with high concentrations of polyphenols and polysaccharides have been tested and compared when conducting this study (Tel-Zur \& al., 1999; Stange \& al., 1998; Porebski \& al., 1997; Lodhi \& al., 1994), including one protocol specifically designed for DNA extraction from in vitro material of the carnivorous plant Drosera rotundifolia (Bekesiova \& al., 1999). None of these methods, however, enabled us to obtain total genomic DNA suitable for PCR from the carnivorous plant taxa used in this study. Consequently our broad and long-term research on carnivorous plants and problems with DNA extraction spurred the development of a more reliable method of obtaining high quality DNA from leaves of carnivorous plants, irrespective of the plant tissue used for extraction. Therefore, a standard protocol for quick and easy genomic DNA extraction from a NucleoSpin Plant kit (Macherey-Nagel, Germany) was modified to fulfil the specific needs when dealing with DNA isolation from carnivorous plant material rich in secondary metabolites, polyphenols and polysaccharides.

\section{Material and methods}

\section{Plant material}

Plant samples from herbarium specimens and living plants from tissue culture were obtained from various sources (see Table 1 for details).

\section{Reagents and solutions}

- Buffer C0 solution (cat. no. 740570.250, Macherey-Nagel (M-N)).

- $5 \%$ sodium N-lauroyl sarcosine (w/v) (Sigma).

- $10 \%$ PVP (polyvinyl-pyrrolidone) (w/v) (Sigma).

- $5 \mathrm{M} \mathrm{NaCl}$.

- RNase A solution (cat. no. 740505, M-N).

- Buffer C4 solution (cat. no. 740935, M-N).

- Phenol:chloroform (1:1 v/v).

- Chloroform:isoamyl alcohol (24:1 v/v).

- Ethanol (100\%).

- Buffer CW (cat. no. 740932, M-N).

- Buffer C5 solution (cat. no. 740931, M-N).

- Elution buffer CE (cat. no. 740570.250, M-N).

PVP, sodium $\mathrm{N}$-lauroyl sarcosine and $\mathrm{NaCl}$ solutions are sterilized by autoclaving.

\section{DNA extraction}

This method for DNA extraction is a modified version of the NucleoSpin® Plant kit standard user manual "Genomic DNA from Plant" (Macherey-Nagel, 2007).

The plant samples are homogenized, for fresh leaf tissue preferably by grinding in a mortar under liquid nitrogen. Dried herbarium specimens or silica dried material is best homogenized using an automatic retch. To achieve lysis of the plant cells, the (frozen) powder is transferred into a capped microfuge tube. Following the protocol of the manufacturer of the MN NucleoSpin ${ }^{\circledR}$ Plant kit (Macherey-Nagel, 2007) $400 \mu \mathrm{l}$ buffer $\mathrm{C} 0$ (preheated to $45^{\circ} \mathrm{C}$ ) are added. In addition to the original recipe, we add $94 \mu 15 \mathrm{M} \mathrm{NaCl}$, $120 \mu \mathrm{l}$ of $5 \%$ sodium N-lauroyl sarcosine and $60 \mu \mathrm{l}$ 
$10 \%$ PVP to the suspension. Following the recommendations of the M-N protocol, $10 \mu \mathrm{l}$ Rase A solution are added to the lysis mixture, and the suspension is vortexed thoroughly. The lysis mixture is now incubated for $60 \mathrm{~min}$. at $60^{\circ} \mathrm{C}$ in a water bath, and mixed 3-4 times during the incubation step by inverting the tubes once or twice.

We extract the lysate with an equal volume (c. $680 \mu \mathrm{l})$ of phenol: chloroform. After centrifugation at 7,100 g for $10 \mathrm{~min}$. at $4{ }^{\circ} \mathrm{C}$, the supernatant (aqueous phase) is transferred into a new microfuge tube. An equal volume (c. $680 \mu \mathrm{l})$ of chloroform:isoamyl alcohol is added, and the samples are centrifuged at 7,100 $\mathrm{g}$ for $10 \mathrm{~min}$. at $4^{\circ} \mathrm{C}$ again. Now $300 \mu \mathrm{l}$ of the supernatant (aqueous phase) is transferred to a new microfuge tube, and 300 $\mu \mathrm{l}$ of buffer $\mathrm{C} 4$ and $200 \mu \mathrm{l}$ ethanol are added. The solution is mixed by inverting the tube 2-4 times. From this step on, the modified protocol is processed following exactly the protocol " 5.1 Genomic DNA purification with NucleoSpin ${ }^{\circledR}$ Plant (lysis buffer C1 and C0)" in the user manual. A NucleoSpin ${ }^{\circledR}$ Plant column (cat. no. $740570.250, \mathrm{M}-\mathrm{N}$ ) is placed into a new NucleoSpin ${ }^{\circledR}$ collecting tube $(2 \mathrm{ml}$, cat. no. $740600, \mathrm{M}-\mathrm{N}$ ), on which the sample is loaded. It is centrifuged for $1 \mathrm{~min}$. at $11,000 \mathrm{~g}$, and the flowthrough is discarded afterwards. For the first washing step, $400 \mu \mathrm{l}$ of buffer CW is added to the column, the sample is centrifuged for $1 \mathrm{~min}$. at $11,000 \mathrm{~g}$, and the flow-through is discarded. The second washing step is performed by adding $700 \mu \mathrm{l}$ of buffer $\mathrm{C} 5$ to the column, centrifugation for $1 \mathrm{~min}$. at $11,000 \mathrm{~g}$ and discard of the flow-through.

In the following washing step, $200 \mu \mathrm{l}$ of buffer C5 are added to the column, which is afterwards centrifuged for $2 \mathrm{~min}$. at $11,000 \mathrm{~g}$ to remove residual buffer $\mathrm{C} 5$ and dry the silica membrane. The column is now placed into a new $1.5 \mathrm{ml}$ centrifuge tube. For elution, we pipette $100 \mu$ lof elution buffer CE (preheated to $70^{\circ} \mathrm{C}$ ) onto the membrane of the column (using $50 \mu \mathrm{l}$ will result in higher concentrated DNA eluate). After a $5 \mathrm{~min}$. incubation at room temperature, the column is centrifuged for $1 \mathrm{~min}$. at $11,000 \mathrm{~g}$ to elute the DNA.

\section{DNA quantification}

The concentration of total genomic DNA isolated with both the standard protocol "Genomic DNA from Plant" (Macherey-Nagel, 2007) and our modified protocol was determined fluorimetrically on the basis of absorbance at $260 \mathrm{~nm}$ by using a PicoGreen ${ }^{\circledR}$ dsDNA Quantitation Reagent fluorescent nucleic acid stain (Molecular Probes), following the manufacturer's protocol.

\section{DNA amplification}

The isolated genomic DNA was analyzed by standard methods for PCR amplification and agarose gel electrophoresis. The primer pairs used for amplification were ITS1 and ITS4 (White \& al., 1990) for members of Ericales and Nepenthales and rbcLaF and rbcLcR (Hasebe \& al., 1994) of the rbcL chloroplast region for Lamiales taxa sampled. Reactives and concentrations used for the PCR amplifications were as follows, for a final content of $100 \mu \mathrm{l}$ in the reaction tube: $1 \mu$ l of DNA template, $81.5 \mu \mathrm{l}$ of aqua bidest., 5 $\mu \mathrm{l}$ of dNTP mix (2.5 mM, ABGene, Germany), $10 \mu \mathrm{l}$ of PCR reaction buffer (10x ThermoPol, New England BioLabs), $0.25 \mu \mathrm{l}$ of each primer solution (MWG-Biotech, Germany) and $2 \mu \mathrm{l}$ of Taq poly-

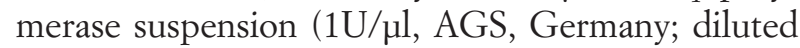
to $1: 10$ before use). The amplification profile consisted of $94^{\circ} \mathrm{C}\left(3 \mathrm{~min}\right.$.), 40 cycles of $94^{\circ} \mathrm{C}(30 \mathrm{~s}) / 54.5^{\circ} \mathrm{C}$ $(30 \mathrm{~s}) / 72^{\circ} \mathrm{C}(75 \mathrm{~s})$ and a final extension of $10 \mathrm{~min}$. at $72^{\circ} \mathrm{C}$ for ITS and of $94^{\circ} \mathrm{C}(3 \mathrm{~min}),$.34 cycles of $94^{\circ} \mathrm{C}$ $(60 \mathrm{~s}) / 54.7^{\circ} \mathrm{C}(60 \mathrm{~s}) / 72^{\circ} \mathrm{C}(90 \mathrm{~s})$ and $10 \mathrm{~min}$. at $72^{\circ} \mathrm{C}$ for $r b c \mathrm{~L}$ respectively.

\section{Results and discussion}

Total genomic DNA prepared with our protocol showed no degradation. It was tested for molecular use by performing PCR-reactions and restriction analysis, both of which were successful.

The concentration of total genomic DNA is given in Table 1. In most samples, the concentration of total genomic DNA eluted was higher when following the Macherey-Nagel standard protocol, compared to our modified protocol (see Table 1 and DNA bands in Fig. 1). The loss of DNA yield in our extraction protocol was $30 \%$ on average compared to the standard protocol (but ranging from $5 \%$ to $60 \%$, depending on the plant species; see Table 1). However, in most cases, DNA obtained from the standard extraction method could not be used for PCR reactions, even if the template was more diluted (1:1, 1:10, 1:100 using aqua dest.) in order to reduce the concentration of secondary metabolites.

PVP and N-lauroyl sarcosine were used to eliminate polyphenols from the DNA extraction procedure (Maliyakal, 1992; Doyle \& Doyle, 1987; Bekesiova \& al., 1999) during cell lysis. PVP binds effectively to polyphenolic compounds which can then be separated from DNA by centrifugation (Maliyakal, 1992). In our protocol this is achieved in the phenol:chloroform extraction step. In addition, N-lauroyl-sarcosine is used as an antioxidant to avoid oxidation of polyphenolic plant components in the suspension during lysis. 


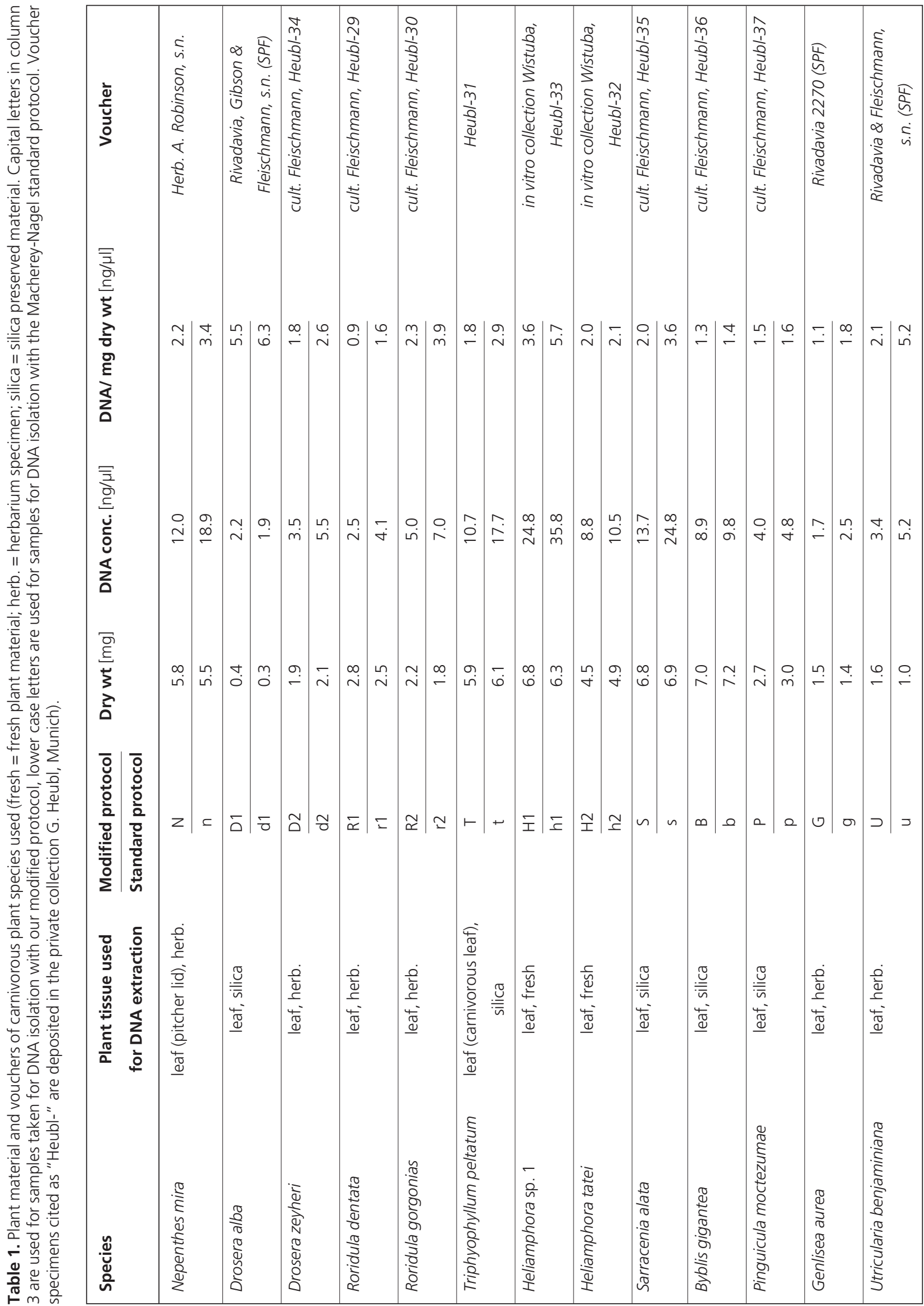




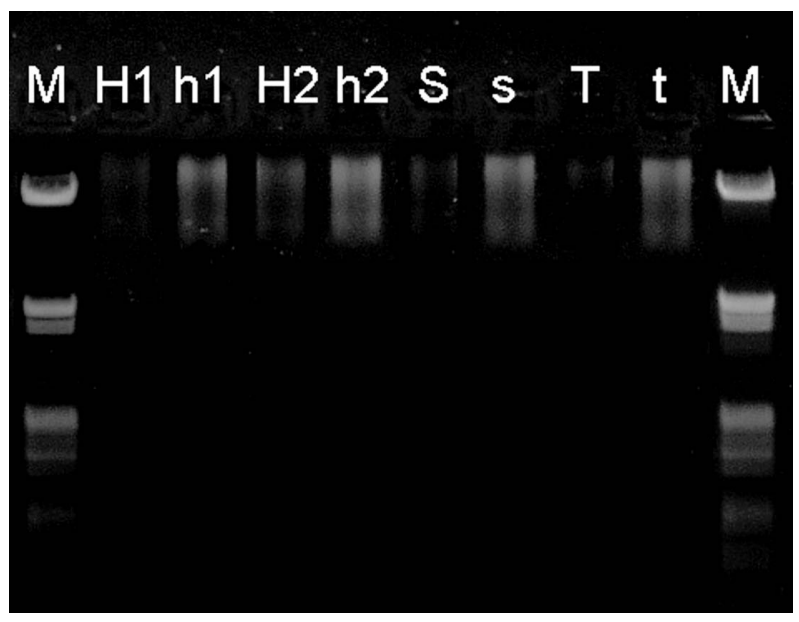

Fig. 1. DNA isolation from carnivorous plant taxa. Ethidium bromide-stained $1 \%$ agarose gel of undigested total genomic DNA extracted from leaves of various carnivorous plant taxa. Capital letters used for DNA obtained with the modified protocol, lower case letters used for DNA isolated using the standard Macherey-Nagel NucleoSpin Plant kit user manual "Genomic DNA from Plant". M: lambda DNA ladder (Thermo Fisher Scientific). Lanes H1/h1: Heliamphora sp. 1. H2/h2: Heliamphora tatei. S/s: Sarracenia alata. T/t: Triphyophyllum peltatum. Vouchers see Table 1.

The combination of both 10\% PVP and N-lauroyl sarcosine during cell lysis of the plant tissue yields in increased amounts of pure total genomic DNA isolates compared to the separate usage of both agents. The presence of oxidized phenolic compounds can be reduced further by keeping plant material frozen during homogenization (Katterman \& Shattuck, 1983), this is achieved by grinding fresh plant material in a mortar under liquid nitrogen.
The samples h1, h2, s, d2, n, t, r1, r2, b (for abbreviations, see Table 1) had a dark reddish brown colour after cell lysis (step 2) and this colour did not change until step 11. This colouration is due to the high presence of oxidized polyphenols in the suspension, which bind to the extracted nucleic acids and proteins (Loomis, 1974). During processing with M-N columns the brownish DNA-protein-polyphenol mix attaches to the column membrane and cannot be removed by the wash buffers used. However, the polyphenols are eluted together with the DNA in the elution step. This explains why the DNA obtained from these samples using the standard NucleoSpin ${ }^{\circledR}$ Plant protocol (Macherey-Nagel, 2007) could not be amplified by PCR (see Fig. 2), although a suitable amount of total genomic DNA was isolated (see Table 1).

Polysaccharides can be seen during DNA extraction procedure as the lysis suspension takes on a blurred viscous consistency. The genetic markers chosen could not be amplified by PCR in our studies when polysaccharides were not removed from the DNA preparation. High salt concentrations during cell lysis help to remove polysaccharides, as they increase their solubility in ethanol (Fang \& al., 1992), thus they become dissolved in the lysis buffer but cannot precipitate with the DNA. $\mathrm{NaCl}$ concentrations of $1 \mathrm{M}$, as reported in Fang \& al. (1992), did not result in total removal of polysaccharides of most carnivorous plant tissue used. We observed that concentrations of $5 \mathrm{M} \mathrm{NaCl}$ added to the suspension in the lysis step did result in the highest yields of total genomic DNA (Lodhi \& al., 1994, recommend concentrations of at least $2.5 \mathrm{M} \mathrm{NaCl}$ for DNA isolation from grapevines rich in polysaccharides).

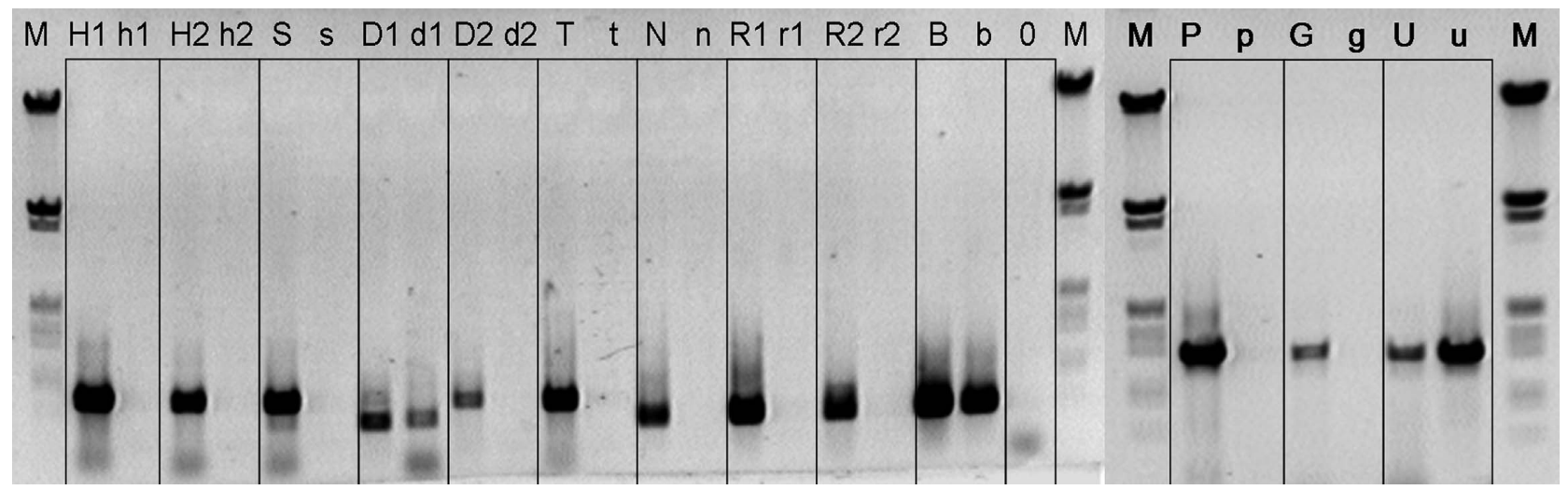

Fig. 2. DNA amplification from carnivorous plant taxa. Ethidium bromide-stained $0.7 \%$ agarose gel of PCR products of DNA obtained from standard and modified Macherey-Nagel protocol. M: lambda DNA ladder (Thermo Fisher Scientific). H1/h1: Heliamphora sp. 1. H2/h2: Heliamphora tatei. S/s: Sarracenia alata. D1/d1: Drosera alba. D2/d2: Drosera zeyheri. T/t: Triphyophyllum peltatum. N/n: Nepenthes mira. R1/r1: Roridula dentata. R2/r2: Roridula gorgonias. B/b: Byblis gigantea. P/p: Pinguicula moctezumae. G/g: Genlisea aurea. U/u: Utricularia benjaminiana. Vouchers see Table 1. For PCR of H1 to b, the nuclear marker ITS was used, for samples P to u the chloroplast marker $r b c L$. The greyscale of the gel is inverted. 
PCR amplification of DNA obtained from our modified protocol was possible due to the absence of contaminants, which could not be removed by the NucleoSpin Plant standard protocol (see Fig. 2). However, DNA of Drosera alba (D1/d1), Byblis gigantea $(\mathrm{B} / \mathrm{b})$ and Utricularia benjaminiana $(\mathrm{U} / \mathrm{u}) \mathrm{did}$ amplify with templates obtained from both protocols. In the first two of these, freshly collected silica dried plant tissue from cultivated plants was used, and the total dry weight was higher than in the samples from herbarium specimens. This might explain a higher yield of total genomic DNA extracted, and therefore a higher content of DNA template for PCR reactions. However, the PCR product yield obtained using the standard protocol was significantly lower in Drosera alba compared to the modified protocol (see Table 1 and DNA bands D1 / d1 in Fig. 2), despite the fact that the concentration of total template DNA was slightly higher when using the standard protocol. Thus a major factor for success in PCR-amplification is not the quantity but the quality of the DNA template used. In the case of Utricularia benjaminiana, the reason why both protocols worked well may be the fact that the tissues of this aquatic plant are soft and pale green, and therefore do not contain high amounts of secondary plant metabolites which can act as contaminants during DNA preparation.

Existing DNA extraction protocols for the carnivorous plant Drosera using the CTAB method (Bekesiova $\&$ al., 1999) are unreliable when considering yield and quality of DNA isolated from plant material which was not grown in vitro. Attempts to obtain DNA from the extraction protocol published by Bekesiova \& al. (1999) with various species of Drosera and other carnivorous plants failed with leaf tissue from fresh, greenhouse grown and field collected plant material, as well as with dried leaves from herbarium specimens. A reason for this might be the fact that Bekesiova \& al. (1999) used in vitro-grown plants of D. spatulata (Figures $1 \mathrm{~A}$ and $1 \mathrm{~B}$ in that paper show $D$. spatulata, not D. rotundifolia). Plants grown on axenic media under artificial lights often exhibit a reduced content of secondary metabolites and light induced phytopigments such as anthocyanins. This is also true for many carnivorous plants, which are less vividly coloured when grown in vitro.

A few carnivorous plant genera have not been tested in this study (the monotypic genera Aldrovanda, Cephalotus, Darlingtonia, Dionaea and Drosopbyllum). In all of these, high numbers of polyphenols and polysaccharides have also been found: flavonoids in Cephalotus (Nicholls \& al., 1985; Jay \& Lebreton, 1972) and Darlingtonia (Jay \& Lebreton, 1972), quinones, phenolics and polysaccharide secretions in Drosopbyllum, Dionaea and Aldrovanda (Schlauer \& al., 2005; Juniper \& al., 1989). Therefore we assume that our protocol will work equally well with these genera to avoid problems caused by secondary plant metabolites in DNA purification or amplification. This protocol has also been tested successfully with some non-carnivorous plants that have high contents of polysaccharides and polyphenols, Mabea (Euphorbiaceae), Oxalis (Oxalidaceae) and Echinopsis (Cactaceae).

\section{Acknowledgements}

The authors would like to thank Fernando Rivadavia, Brazil, and Dr Alastair Robinson, England, for providing plant material from herbarium specimens and Dr Andreas Wistuba, Germany, for providing in vitro grown plant material from tissue culture for this study. The help of Michael Miller of the Zoologische Staatssammlung Munich in determining the DNA amount is acknowledged. Thanks to Tanja Ernst and Florian Turini for technical assistance, to Delsy Trujillo-Chavez for help with the Spanish abstract and to two anonymous reviewers for useful suggestions on the manuscript.

\section{References}

Bekesiova, I., Nap, J.P. \& Mlynarova, L. 1999. Isolation of high quality DNA and RNA from leaves of the carnivorous plant Drosera rotundifolia. Plant Molecular Biology Reporter 17: 269. 277.

Doyle, J.J. \& Doyle, J.L. 1987. A rapid DNA isolation procedure from small quantities of fresh leaf tissues. Phytochemical Bulletin 19: 11-15.

Fang, G., Hammar, S. \& Grumet, R. 1992. A quick and inexpensive method for removing polysaccharides from plant genomic DNA. BioTechniques 13:52-56.

Hasebe, M., Omori, T., Nakazawa, M., Sano, T., Kato, M. \& Iwatsuki, K. 1994. RbcL gene sequences provide evidence for the evolutionary lineages of leptosporangiate ferns. Proceedings of the National Academy of Sciences of the USA 91: 5730-5734.

Jay, M. \& Lebreton, P. 1972. Chemotaxonomic research on vascular plants 26. The flavonoids of the Sarraceniaceae, Nepenthaceae, Droseraceae and Cephalotaceae; a critical study of the order Sarraceniales. Naturaliste Canadienne 99: 607-613.

Juniper, B.E., Robins, R.J. \& Joel, D.M. 1989. The Carnivorous Plants. Academic Press. London.

Katterman, F.R.H. \& Shattuck, V.I. 1983. An effective method of DNA isolation from the mature leaves of Gossypium species that contain large amounts of phenolic terpenoids and tannins. Preparative Biochemistry 13:347-359.

Lloyd, F.E. 1934. Is Roridula carnivorous? Canadian Journal of Research 10: 780-786.

Lodhi, M.A., Ye, G.N., Weeden, N.F. \& Reisch, B.I. 1994. A simple and efficient method for DNA extraction from grapevine cultivars, Vitis species and Ampelopsis. Plant Molecular Biology Reporter 12: 6-13.

Loomis, W.D. 1974. Overcoming problems of phenolics and quinones in the isolation of plant enzymes and organelles. Methods in Enzymology 31(Pt A): 528-544.

Macherey-Nagel. 2007. NucleoSpin®Plant: Genomic DNA from Plant User manual, June 2007/Rev. 6. Macherey-Nagel GmbH \& Co. KG. Düren. 
Maliyakal, E.J. 1992. An efficient method for isolation of RNA and DNA from plants containing polyphenolics. Nucleic Acids Research 20: 2381.

Müller, K., Borsch, T., Legendre, L., Porembski, S., Theisen, I. \& Barthlott, W. 2004. Evolution of carnivory in Lentibulariaceae and the Lamiales. Plant Biology 6: 477-490.

Nicholls, K.W., Bohm, B.A. \& Ornduff, R. 1985. Flavonoids and affinities of the Cephalotaceae. Biochemical Systematics and Ecology 13: 261-263.

Porebski, S., Bailey, L.G. \& Baum, B.R. 1997. Modification of a CTAB DNA extraction protocol for plants containing high polysaccharide and polyphenol components. Plant Molecular Biology Reporter 15: 8-15.

Richards, E. 1988. Preparation of genomic DNA from plant tissue. In: Ausubel, F.M. \& al. (eds.), Current Protocols in Molecular Biology. Greene Publishing Associates and Wiley-Interscience. New York.

Rost, K. \& Schauer, R. 1977. Physical and chemical properties of the mucin secreted by Drosera capensis. Phytochemistry 16: 1365-1368.

Schlauer, J., Budzianowski, J., Kukulczanka, K. \& Ratajczack, L. 2004. Acetoside and related phenylethanoid glycosides in Byblis liniflora Salisb. plants propagated in vitro and its systematic significance. Acta Societatis Botanicorum Poloniae 73: 9-15.

Schlauer, J., Nerz, J. \& Rischer, H. 2005. Carnivorous plant chemistry. Acta Botanica Gallica 152: 187-195.
Sheridan, P.M. \& Griesbach, R.J. 2001. Anthocyanidins of Sarracenia L. Flowers and Leaves. Hortscience 36: 384.

Shioda, M. \& Marakami-Muofushi, K. 1987. Selective inhibition of DNA polymerase by a polysaccharide purified from slime of Physarum polycephalum. Biochemical and Biophysical Research Communications 146: 61-66.

Stange, C., Prehn, D. \& Arce-Johnson, P. 1998. Isolation of Pinus radiata Genomic DNA Suitable for RAPD Analysis. Plant Molecular Biology Reporter 16: 1-8.

Tel-Zur, N., Abbo, S., Myslabodski, D. \& Mizrahi, Y. 1999. Modified CTAB procedure for DNA isolation from epiphytic cacti of the genera Hylocereus and Selenicereus (Cactaceae). Plant Molecular Biology Reporter 17: 249-254.

White, T.J., Bruns, T., Lee, S. \& Taylor, J. 1990. Amplification and direct sequencing of fungal ribosomal RNA genes for phylogenetics. In: Innis, M.A. \& al. (eds.), PCR Protocols - a guide to methods and applications, United Kingdom edition: 315-322. Academic Press. San Diego.

Wollenweber, E. 2007. Flavonoids occurring in the sticky resin on Roridula dentata and Roridula gorgonias (Roridulaceae). Carnivorous Plant Newsletter 36: 77-80.

Associate Editor: J. Diéguez Received: 24-VII-2008 Accepted: 18-V-2009 
